TI 2002-027/3

Tinbergen Institute Discussion Paper

The Value of Human and Social

Capital Investments for the Business Performance of Startups

Niels Bosmal

Mirjam van Praag ${ }^{2}$

Roy Thurik1,3

Gerrit de Wit ${ }^{7}$

1 EIM Business and Policy Research, Zoetermeer,

2 Faculty of Economics and Econometrics, University of Amsterdam,

${ }^{3}$ CASBEC, Faculty of Economics, Erasmus University Rotterdam, and Tinbergen Institute. 
Tinbergen Institute

The Tinbergen Institute is the institute for economic research of the Erasmus Universiteit Rotterdam, Universiteit van Amsterdam and

Vrije Universiteit Amsterdam.

Tinbergen I nstitute Amsterdam

Keizersgracht 482

1017 EG Amsterdam

The Netherlands

Tel.: +31.(0)20.5513500

Fax: $\quad+31 .(0) 20.5513555$

Tinbergen Institute Rotterdam

Burg. Oudlaan 50

3062 PA Rotterdam

The Netherlands

Tel.: $\quad+31 .(0) 10.4088900$

Fax: $\quad+31 .(0) 10.4089031$

Most TI discussion papers can be downloaded at

http://www.tinbergen.nl 


\title{
The Value of Human and Social Capital Investments for the Business Perform- ance of Startups
}

Niels Bosma

EIM Business and Policy Research, P.O. Box 7001, 2701 AA Zoetermeer, the Netherlands, tel. +3179 3413634, e-mail: nbo@eim.nl

Mirjam van Praag

Faculty of Economics and Econometrics, University of Amsterdam, Roeterstraat 11, $1018 \mathrm{WB}$ Amsterdam, The Netherlands, tel. +31 20 205254079, e-mail: vanpraag@fee.uva.nl

\section{Roy Thurik}

Centre for Advanced Small Business Economics (CASBEC), Erasmus University Rotterdam, P.O. Box 1738, 3000 DR Rotterdam, the Netherlands, tel. +31 10 4081398, and EIM Business and Policy Research, P.O. Box 7001, 2701 AA Zoetermeer, the Netherlands, tel. +31 79 3413634, e-mail:

thurik@few.eur.nl

\section{Gerrit de Wit}

EIM Business and Policy Research, P.O. Box 7001, 2701 AA Zoetermeer, the Netherlands, tel. +31 79 3413634, e-mail: gdw@eim.nl

\begin{abstract}
We investigate the manifold posed question: "To what extent does investment in human and social capital, besides the effect of "talent", enhance entrepreneurial performance?" We distinguish between three different performance measures: survival, profits, and generated employment. On the basis of the empirical analysis of a rich Dutch longitudinal data set of firm founders, we conclude that specific investments indeed affect the three performance measures substantially and significantly. Specific attention is paid to the unobserved talent bias. Moreover, the effect of the emergence of so called "knowledge industries" is explored.
\end{abstract}

Version: March 2002

JEL code: M13, D92, J24

Keywords: entrepreneurship, human capital, social capital, small business, startups, performance.

Acknowledgement: This paper has been written in the framework of the research programme SCALES (Scientific AnaLysis of Entrepreneurship and SMEs), which is financed by the Dutch Ministry of Economic Affairs. We acknowledge the support of Hessel Oosterbeek and the comments of Jan de Kok and Lorraine Uhlaner. Earlier versions of the paper have been read at the RENT Conference in Prague, November 2000 and the Babson Conference in Jönköping, Sweden, June 2001. 


\section{Introduction}

Investments in human and social capital are widely believed to improve the performance of employees (Arthur, 1994; Bishop, 1994; Boselie, Paauwe and Jansen, 2001; Gelderblom and de Koning, 1996; Huselid, 1995; MacDuffie, 1995). Similarly, many authors advocate that this is also the case for entrepreneurial performance (Blanchflower and Oswald, 1998; Brüderl and Preisendörfer, 1998; Cooper, Gimeno-Gascon and Woo, 1994; Pennings, Lee and Van Witteloostuijn, 1998; Van Praag and Cramer, 2001; Van Praag, 2002). This is easy to understand since entrepreneurship is a fundamental characteristic of modern knowledge-based economic activities. This is because the potential value of new ideas and knowledge is inherently uncertain. This uncertainty can be absorbed by a large amount of people starting new firms to pursue, explore and implement new ideas (Audretsch and Thurik, 2000, 2001).

The objective of the present paper is to answer the question: to what extent does investment in human and social capital, besides the widely believed determining effect of "talent", enhance entrepreneurial performance? We distinguish between three types of investment in both human and social capital: general, industry-specific and entrepreneurship-specific investment. We will investigate to what degree these types of initial investment contribute to the performance of the small business founder, our empirical equivalent of the entrepreneur. The analysis is based on a representative panel survey amongst almost 1,000 new business founders in the Netherlands in the years 1994-1997. We employ three measures of performance: survival, profit, and generated employment.

Our main finding is that the endowed level of talent of a small business founder is not the unique determinant of performance. Rather, investment in industry-specific and entrepreneurshipspecific human and social capital contributes significantly to the explanation of the cross-sectional variance of the performance of small firm founders. More precisely: industry-specific investments in human capital such as experience in the specific industry enhance performance, irrespective of the performance measure used. In addition, human and social entrepreneurship-specific capital investments, such as earlier experience in starting up a business and the membership of an association for small business founders generate more promising start-ups.

This paper attempts to further our understanding about effective general and specific investments in human and social capital of small business founders. We seek to contribute to a policyrelevant and ongoing debate in the entrepreneurship literature. Empirical studies into the effect of human capital (Cooper, Gimeno-Gascon and Woo, 1994; Van Praag and Cramer, 2001) and social capital (Brüderl and Preisendörfer, 1998; Pennings, Lee and Van Witteloostuijn, 1998) on the performance of business founders are no novelty. The same holds for the distinction between the effect on performance of general and specific investments (Cooper, Gimeno-Gascon and Woo, 1994; Pennings, Lee and Van Witteloostuijn, 1998) in human and social capital. The contribution of this study is twofold. First, we systematically test the effect of general, industry-specific and entrepreneurship-specific human and social capital on three distinct performance measures while controlling for a rich set of other factors. Second, we explicitly analyze the meaning of our result by exploring alternative explanations that are often not considered (Pennings, Lee and Van Witteloostuijn, 1998; Cooper, Gimeno-Gascon and Woo, 1994).

\section{Theory and hypotheses}

It is argued that the firm founder's performance is determined not only by his talent, the circumstances and good luck, but also by his human, social, and financial capital. We measure the impact of human, social and financial capital on the firm's performance, while we control as much as possible for the other factors mentioned. In our view firm performance can be used as a proxy for the performance of the firm's founder because usually no other human capital than that of the single founder is present in the first year of a business startup. Pennings, Lee and Van Witteloostuijn (1998) propose two reasons for a positive association between ownership share and the rela-

tive contribution of capital to firm performance: First, owners are residual claimants and therefore have a stronger incentive to use their human capital to the benefit of the firm. Second, the rents 
associated with investments in general assets completely accrue to the firm in case of an owner, whereas this is less so in case of a fixed claimant with outside options.

Our focus is on the impact of human and social capital. We are particularly interested in the entrepreneurship-specific and industry-specific investments in these types of capital.

\section{Human capital}

The positive impact of human capital on employee performance is well accepted and was formalized by Mincer (1974). Van Praag and Cramer (2001) made a first attempt to formalize this impact for the business founder's case. Several authors, including Cooper, Gimeno-Gascon and Woo (1994), Pennings, Lee and Van Witteloostuijn (1998), Van Praag (2002, 1999, 1996) as well as De Wit and Van Winden (1989) have put forth empirical support for the theoretical foundation.

Hypothesis 1. Higher levels of human capital are associated with stronger performance by business founders

\section{Social capital}

As far as we know, the impact of social capital on a business founder's performance has not yet been put in a proper theoretical perspective. However, its impact has been supported empirically by Blumberg and Pfann (1999), Brüderl and Preisendörfer (1998) and Pennings, Lee and Van Witteloostuijn (1998). A theory of investment in individual social capital has recently been developed by Glaeser, Laibson and Sacerdote (2000). For the benefit of identifying determinants of social capital formation, Glaeser, Laibson and Sacerdote first seek to understand the social capital investment decision of individuals. This understanding leads to seven propositions of which a subset is relevant: (i) a rational individual's investment in social capital is higher in occupations with greater returns to social skills, (ii) social capital declines with expected mobility, (iii) people who invest in human capital also invest in social capital. Since small business founders need to have stronger or weaker ties with all the (prospective) stakeholders in their firm, such as clients, investors, debtors and, subcontractors, the expected benefits pertaining to social skills are high in the "occupation" of business founding. Furthermore, we know that business founders are less mobile than employees are (Blanchflower, 2000). This implies by proposition (ii) of Glaeser, Laibson and Sacerdote that the expected returns to social capital are higher than average for business founders. The third proposition of Glaeser, Laibson and Sacerdote implies that individuals for whom the net return to human capital is high also might expect a relatively high net return to social capital. Taken together, these three propositions imply that social capital should enhance the performance of a business founder.

Hypothesis 2. Higher levels of a business founder's social capital are associated with greater performance of the firm.

\section{Productivity and signaling}

The impact of human and social capital on the performance of the firm is likely to be caused by two underlying forces: productivity and signaling. First, the more capital is embedded in the firm's founder, the greater is the firm's productivity, and second, prospective stakeholders such as clients, subcontractors, and investors are likely to have imperfect information about the type of firms they consider dealing with. Therefore, these parties evaluate firms (and the prices involved in for instance buying their services) based on observable characteristics that they presume to be correlated with the unobserved type/quality of the firm and its founder. Investment in social and human capital might be a signal (Spence, 1974) as long as a high investment in these types of capital is the preferred choice of talented people, whereas a low level of investment is the most preferred choice for people with less talent (Milgrom and Roberts, 1992). We shall return to this interpretation when discussing the self-selection interpretation.

\section{Specificity of investments}

We differentiate the firm founder's capital investments with respect to the specificity of the investment. It is well known both from human capital theory (Becker, 1964) and from resourcebased theories of the firm (Montgomery, 1995) that the more specific an investment is to its cur- 
rent use, the higher the expected returns, i.e., its contribution to firm performance should be. According to the human capital theory, the returns to a deliberate specific investment in a current activity should be sufficiently large to outweigh the cost attached to the investment. Contrarily, the returns to an investment in a more general asset might accrue to the investor during a longer period of time while performing various activities. Moreover, according to resource-based theories of the firm, success of firms is determined by the extent to which Ricardian rents are earned by the accumulation and deployment of non-imitable resources. The probability of resources to be nonimitable is higher when they are obtained through specific investment than when by more general investment. We contrast general investments with two types of specific investments in human and social capital: industry-specific next to entrepreneurship-specific investments. Industry-specific investments lose (part of) their value outside the industry in which the business venture is started whereas entrepreneurship-specific investment loses its return outside the entrepreneurial environment. Our next hypothesis results:

Hypothesis 3. Industry-specific and entrepreneurship-specific investments in the business founder's human and social capital are more influential on firm performance than are general investments in human and social capital.

\section{Self-selection and unobserved heterogeneity}

Theoretically, investment behavior is in line with the comparative advantages hypothesis: individuals who experience more than average net gains from a particular investment, are more likely to choose that investment option. In other words, individuals self-select themselves into certain "treatment groups". The comparative advantage underlying the type of investment decisions that we study depends on individual characteristics that remain partly unobserved. The unobserved part of these characteristics about which the investor has private information, such as talent and intelligence, however, probably not only affects the outcome of the investment decision but also the performance of the business venture.

From a more technical point of view, the above implies that the unexplained part of the crosssectional variation in business founders' performance is correlated with the levels that these individuals invest in human and social capital. This correlation can be positive or negative. Most probably, the cost pertaining to the investment is lower for business founders with "higher" abilities than for business founders with "lower" abilities. Therefore, given a fixed difference in benefits accruing to the business founder of either ability level, a positive correlation between the error term and the investment levels in human and social capital is expected. If the level of benefits has the same association with the unobserved factors as business performance has, the correlation is surely positive. However, if lower ability business founders expect higher benefits from their investment than do higher ability entrepreneurs, because the latter group might judge that they "don't need" these investments and, if this effect is stronger than the opposite effect at the costside, a negative correlation between the error term and the investment might result.

Summarizing, failing to implement the deliberate investment decision in the empirical model could generate a misspecified model with biased estimates.

Hypothesis 4. The choice of firm founders for specific investments is partly dependent on unobserved talent of the firm founders. This would lead to biased estimates of the effect of these investments.

\section{"Knowledge industries"}

The relative contribution to production of human capital and knowledge has rapidly increased over the past decade (Audretsch and Thurik, 2000). This is the case particularly in the so-called "knowledge industries", such as the ICT industry. Hence, one might argue that specific investments in human and social capital are particularly relevant in these "knowledge industries". In the most extreme case, the effect of human capital on performance that we interpret as a general effect, might be the pure result of the supposedly strong effect in this growing industry, whereas the effect of human capital on performance in other industries might be insignificant. 
Hypothesis 5. Industry-specific and entrepreneurship-specific investments in the business founder's human and social capital are more influential in the "knowledge industries" than they are in other industries.

\section{Method}

\section{Sample}

The panel consists of annual questionnaires conducted on a sample of Dutch entrepreneurs that started their business in 1994. The sample was taken from all newly registered firms in the first quarter of 1994 as reported in the database of the Dutch Chamber of Commerce. Initially 10,627 firms were contacted by telephone. A total of 3,000 firm founders agreed to participate in the survey. Approximately 2,000 firm founders finally completed the 1994 questionnaire. From 1995 onwards, a questionnaire was sent to the remaining group of business founders. The 1997 questionnaire was completed by over 1,100 respondents, implying a cumulative attrition rate of $45 \%$. The firm size and sector distribution of the 1994 and 1997 respondents were comparable to those of the initial sample.

As nearly half of the firm founders left the panel between 1994 and 1997, either due to nonrespons or the firm's exit, one could suspect that this could lead to biased results. We constructed an explicit model to investigate possible biases and found no significant ones.

The measures for entrepreneurial performance are constructed from the questionnaires in 1995, 1996 and 1997, whereas the possible determinants are derived solely from the 1994 questionnaire. In this way we prevent problems of reversed causality.

\section{Measures of entrepreneurial performance}

The dataset used provides three performance measures. The first one deals with profit and is equated to the profit made in 1997. The entrepreneur has then been active for three years. Especially in the first two years profit may be somewhat misleading, as initial (sunk) costs often have to be gained back, which reduces profit. For entrepreneurs that are known to have terminated their businesses the profit variable is equated to zero. The second measure used is the cumulative employment created in the period 1994-1997. ${ }^{1}$ While profit is mainly an individual performance measure, the employment created by an entrepreneur can be seen as a society performance measure. The third performance measure is the hazard out of business ownership. Information is available on the survival time of the firms in the panel. We have constructed a variable measuring the number of months that a firm has been active. A survival model will be applied when investigating this performance measure.

\section{Determinants of entrepreneurial performance}

From the 1994 firm founders questionnaire, we derived possible determinants of performance as set out in Table 1 . The variables are grouped horizontally by measure of specificity and vertically by the form of capital. Following the arguments made earlier, we focus on the five variables listed in italics in Table 1.

\footnotetext{
${ }^{1}$ Other employment measures have also been investigated. These include employment growth and the employment in 1997. Both measures produced results that did not differ significantly from those pertaining to the performance measure "cumulated employment". We therefore included cumulated employment as the single employment measure in this paper.
} 
Table 1: Potential determinants of entrepreneurial performance

\begin{tabular}{|c|c|c|c|c|}
\hline & Human Capital & Social Capital & Financial Capital & Controls \\
\hline $\begin{array}{l}\text { Entrepreneurship- } \\
\text { specific invest- } \\
\text { ments }\end{array}$ & $\begin{array}{l}\text { Experience in busi- } \\
\text { ness ownership } \\
\text { Experience in ac- } \\
\text { tivities relevant to } \\
\text { business ownership }\end{array}$ & $\begin{array}{l}\text { Contact with } \\
\text { entrepreneurs in } \\
\text { networks } \\
\text { Way of informa- } \\
\text { tion gathering }\end{array}$ & $\begin{array}{l}\text { Experienced prob- } \\
\text { lems getting start } \\
\text { capital }\end{array}$ & \multirow{3}{*}{$\begin{array}{l}\text { Various controls } \\
\text { such as gender, } \\
\text { roots of the } \\
\text { firm, initial ob- } \\
\text { jectives and } \\
\text { ambitions of the } \\
\text { founder, labor } \\
\text { market histories, } \\
\text { etc. }\end{array}$} \\
\hline $\begin{array}{l}\text { Industry-specific } \\
\text { investment }\end{array}$ & $\begin{array}{l}\text { Experience in in- } \\
\text { dustry }\end{array}$ & & & \\
\hline $\begin{array}{l}\text { General invest- } \\
\text { ment }\end{array}$ & $\begin{array}{l}\text { Age } \\
\text { Age squared } \\
\text { High education } \\
\text { Experience as an } \\
\text { employee }\end{array}$ & $\begin{array}{l}\text { Emotional sup- } \\
\text { port from } \\
\text { spouse } \\
\text { Presence of } \\
\text { spouse }\end{array}$ & $\begin{array}{l}\text { Other income } \\
\text { sources }\end{array}$ & \\
\hline
\end{tabular}

We include seven human capital variables. Experience of the business founder is measured in different dimensions: experience in business ownership itself, experience in activities related to business ownership (e.g. experience in leadership), and experience in the industry in which the founded business is active. For analyzing the effect of age, the inclusion of age and age squared enables a nonlinear relation. Education enters the analyses as a dummy variable, differentiating the high-educated business founders from the less educated ones. Like in many other studies, a dummy variable indicating whether the respondent has experience as an employee is also included.

The three social capital variables are the following. If the business founder is engaged in an organized network of entrepreneurs (like a rotary club) this is indicated. Also, the emotional support of the business founder's spouse may be important for entrepreneurial performance. To measure this effect properly, the presence of a spouse is also included as a dummy variable. Finally, the way the entrepreneur plans his way of information gathering may be influential for his performance. In the questionnaire ten possible actions were shown to the entrepreneurs. The respondents indicated whether they frequently, sometimes or never made use of these actions. Some of these actions are closely related. Factor analysis revealed four major strategies with respect to planned information gathering among the Dutch business founders:

1. Focus on the branch in general (main actions: keep up with literature; attending conferences, courses and industry exchanges);

2. Focus on direct business relations (main actions: information from customers and suppliers);

3. Focus on commercial relations (main actions: information from banks; commercial cooperation; advise from experts);

4. Focus on fellow entrepreneurs.

From the financial angle, two variables are distinguished. The amount of the remaining income available in the household of the business founder may affect his/her performance. Thus, we include the amount of remaining income received by the business owner. We also identify the business founders that experienced a financial capital constraint by a unique dummy variable with value 1 if the business founder experienced problems obtaining start capital.

\section{Estimation methods}

Both the profit and the employment measure have a zero lower bound. Negative profits are not observed, while negative employment is non-interpretable. Therefore, both equations are estimated using tobit regressions. For the expected survival time, we apply a different model than for profit and employment. In this survival model the (logarithm of the) expected survival time is modelled as a function of the characteristics of the entrepreneurs. For the underlying expected distribution of the probability to exit, we assume a log-logistic distribution (Lancaster, 1992, p. 8). See the Appendix to this paper for details. 


\section{Results}

Estimation results are presented in Table 2. From this table we will draw some conclusions concerning hypotheses 1, 2 and 3 of section 2 . We will also make some additional observations. Section 5 will deal with additional analyses meant to test the remaining hypotheses 4 and 5 .

Table 2: Estimation results: Impact of Human and Social Capital on Performance

\begin{tabular}{|c|c|c|c|}
\hline human capital & Survival time & Profit & Employment \\
\hline Experience in business ownership & & $(0.40)$ & \\
\hline $\begin{array}{l}\text { Experience in activities relevant to } \\
\text { business ownership }\end{array}$ & 0.50 & & \\
\hline Experience in industry & 0.50 & 0.62 & 0.49 \\
\hline \multicolumn{4}{|l|}{ Age divided by 10} \\
\hline \multicolumn{4}{|l|}{ Age divided by 10 , then squared } \\
\hline High education & & 0.25 & \\
\hline Experience as an employee & & & 1.18 \\
\hline \multicolumn{4}{|l|}{ social capital } \\
\hline Contact with entrepreneurs in net- & & & 0.81 \\
\hline Way of information gathering: & & & \\
\hline - general channels & 0.28 & & 0.32 \\
\hline - direct business relations & & & \\
\hline - commercial relations & $(0.20)$ & 0.16 & 0.33 \\
\hline - fellow entrepreneurs & & 0.15 & \\
\hline Emotional support from spouse & 0.57 & 0.40 & \\
\hline Presence of spouse & $(-0.59)$ & & $(0.81)$ \\
\hline \multicolumn{4}{|l|}{ financial capital } \\
\hline Other income available & & $(-0.05)$ & -0.13 \\
\hline Experienced problems getting start & -0.66 & -0.47 & \\
\hline \multicolumn{4}{|l|}{ control variables } \\
\hline Gender & 0.47 & 0.43 & 0.54 \\
\hline No affiliations with other businesses & 0.94 & 0.75 & \\
\hline Goal: employment growth & & 0.44 & 2.39 \\
\hline Motive: higher income & & $(0.26)$ & \\
\hline Number of hours worked at the start & 0.38 & 0.34 & 0.83 \\
\hline Constant & $(3.71)$ & -2.56 & -5.12 \\
\hline \# observations & 821 & 896 & 758 \\
\hline Log likelihood & -935.66 & -1217.53 & -639.97 \\
\hline
\end{tabular}

Business founders spending 40 hours or more on other paid activities are left out. Only significant results are presented. Results are significant at the 5\%-level unless they are in parentheses in which case they are only significant at the $10 \%$-level.

Human capital appears to influence our entire set of performance measures. To be more specific, former experience of the business founder in the industry in which he starts his business appears to improve all performance measures. Moreover, experience in activities relevant to business ownership (e.g. experience in leadership) increases the firm's survival time. Age appears to affect none of the performance measures. Finally, high-educated people make more profits, while those who have experience as an employee create more employment. Leaving out the human capital variables results in a model that according to the likelihood ratio tests performs significantly worse for all three performance measures. We conclude that hypothesis 1 - human capital influences the performance - is confirmed, though the specific aspects of human capital that influence each performance measure are not similar.

Social capital also appears to influence performance. If business owners plan to gather their information via commercial relations, this improves several performance measures. Furthermore, 
information gathering via general channels further increases the survival time and the generated employment. Contact with other entrepreneurs in networks, such as rotary clubs, has a positive effect on the employment the business founder generates. The effect of these formal networks is insignificant on the other performance measures. Finally, the emotional support of a spouse appears also to be of importance: those who enjoy it earn approximately $40 \%$ more than their fellow entrepreneurs who experience no support. On the whole, we conclude that there is sufficient support for hypothesis 2: social capital positively affects entrepreneurial performance.

The specific investments in human and social capital are printed in italics in Table 2. It appears that making specific investments matters in explaining performance. Exclusion of variables related to specific investments results in a model with a significantly lower likelihood than the model with these variables included. However, as can be seen from the table, general investments in human and social capital are also of importance - be it somewhat less. ${ }^{2}$ Thus, there is some support for hypothesis 3: specific investments are more influential than general investments.

With respect to the influence of financial capital, we find that capital constraints at the start have a negative impact on survival time and earnings. Those business owners who already have another source of finance perform worse as regards to generating employment. They are probably not as dedicated to their business than their fellow entrepreneurs.

With respect to our controls, the following results are worth mentioning. Gender matters, at least for this particular sample of 1994 Dutch business founders. Male business founders perform better on all performance measures. Having no affiliations with other businesses works out positive: it increases the survival time as well as the profits generated. Finally, people indicating that one of their goals is achieving employment growth, indeed generate more employment and people who indicate that a higher expected income is an important motive to become self-employed indeed make more profits.

\section{Final discussion}

In the previous section we found that specific investments of firm founders in human or social capital enhance their performance. However, as explained in section 2, without further explorations one cannot be sure whether this positive effect is solely due to the investment itself or partly due to the fact that more talented firm founders invest more in their human and social capital. In the latter case it would be incorrect to assign the credits of the better performance solely to the investment. In other words, we would have found an upwardly biased effect.

This problem is widely recognized in the schooling literature (Ashenfelter, Colm and Oosterbeek, 2000) and can be solved with instrumental variables estimation techniques. In this technique, the model is enhanced with an additional equation describing the investment decision of the firm founders in a particular form of human or social capital. The additional investment equation should contain at least one variable, the "instrument", which (i) has a significant effect on the investment decision, while (ii) it cannot influence the performance of the firm founder on theoretical grounds. In this way it is possible to sort out the "real" investment effect. For, if the instrument is found to have an effect in the performance equation, it is then clear that this effect can only be due to the investment because by assumption the instrument has no direct effect on performance.

Unfortunately, as is commonly known, it is notoriously difficult to find appropriate instruments. Although we tried various ones, we were not able to find satisfying instruments. So potential biases in this way cannot be ruled out. Nevertheless, we do not suspect large biases to occur because of the following two reasons. First, using our rich data set we already control for talent in our regression with several proxies. This leaves less room for unobserved talent correlated with the investment decision of the firm founder. Second, on theoretical grounds we do not suspect large biases for most of our investments variables. For example, we find that firm founders with experience in the industry in which they start their businesses, perform better. It is unlikely that this ef-

\footnotetext{
${ }^{2}$ More precisely, exclusion of the variables related to general investments decreases the likelihood less than exclusion of the variables related to specific investments.
} 
fect would be due largely to unobserved talent of these firm founders. Hence, though we are not able to reject hypothesis 4 unreservedly - there are biases because of unobserved talent - we are not afraid for large biases in our results because of it.

An obvious competitor for the influence of human and social capital on performance is the use of strategies which again needs to be controlled for types of uncertainty (Van Gelderen, Frese and Thurik, 2000). A certain strategy may dictate what types and levels of human and social capital are needed. Alternatively, available types and levels of human and social capital may induce to application of certain strategies. Future research needs to take into account the interrelationships between the portfolio of human and social capital, types of strategy, forms of uncertainty and performance.

For exploring the role of the knowledge industries in explaining performance (hypothesis 5), dummy varaibles for these industries (i.e. business services and other services) are implemented. For the specific investment variables, cross products are generated and included in the analysis. However, the hypothesized industry effects does not emerge from the estimation results. On these grounds, we reject hypothesis 5.

We conclude that specific investments in human and social capital enhance entrepreneurial performance substantially. This is true for all three distinguished performance measures: survival, profits, and generated employment. 


\section{References}

Arthur, J.B. (1994) "Effects of human resource systems on manufacturing performance and turnover", Academy of Management Journal 37(3), 670-687.

Ashenfelter, O., H. Colm and H. Oosterbeek (1999) "A review of estimates of the schooling/earnings relationship, with tests for publication bias", Labour Economics (6)4, 453-470.

Audretsch, D.B. and A.R. Thurik (2000) "Capitalism and democracy in the 21st century, from the managed to the entrepreneurial economy", Journal of Evolutionary Economics 10, 17-34.

Audretsch, D.B. and A.R. Thurik (2001) "What is new about the new economy: sources of growth in the managed and entrepreneurial economies", Industrial and Corporate Change 10(1), 267-315.

Becker, G. S. (1964) Human Capital, New York: Columbia University Press.

Bishop, J. (1994) "The impact of previous training on productivity and wages", in L. Lynch (ed), Training and the Private Sector, Chicago: University of Chicago Press, 161-200.

Blanchflower, D.G. (2000) "Self-employment in OECD countries", Labor Economics 7, 471-505.

Blanchflower, D.G., and A. J. Oswald (1998) "What makes an entrepreneur?" Journal of Labor Economics 16(1), 26-60.

Blumberg, B.F. and G.A. Pfann (1999) "Social capital and the self-employment decision", unpublished manuscript Maastricht University, Business Investment Research Center.

Boselie, P., J. Paauwe and P. Jansen (2001) "Human resource management and performance: lessons from the Netherlands". International Journal of Human Resource Management, 12(7), 1107-1125.

Brüderl, J. and P. Preisendörfer (1998) "Network support and success of newly founded businesses", Small Business Economics 10, 213-225.

Cooper, A.C., F.J. Gimeno-Gascon and C.Y. Woo (1994) "Initial human and financial capital as predictors of new venture performance", Journal of Business Venturing 9, 371-395.

Gelderblom, A. and J. de Koning (1996) "Evaluating effects of training within a company: methods, problems and one application", Labour 10, 319-337.

Gelderen, M. van, M. Frese and A.R. Thurik (2000) "Strategies, uncertainty and performance of small startups", Small Business Economics 15(3), 165-181.

Glaeser, E.L., D. Laibson and B. Sacerdote (2000) "The economic approach to social capital", NBER Working Paper No. 7728.

Greene, W. H. (1997), Econometric Analysis fourth Edition, New Jersey: Prentice Hall, 1997.

Huselid, M.A. (1995) "The impact of human resource management practices on turnover, productivity, and corporate financial performance", Academy of Management Journal 38(3), 635-672.

Lancaster, T. (1992) "The Econometric Analysis of Transition Data", Cambridge: Cambridge University Press.

MacDuffie, J. P. (1995) "Human resource bundles and manufacturing performance: organizational logic and flexible production systems in the world auto industry", Industrial and Labor Relations Review 48(2), 197-221.

Milgrom, P. and J. Roberts, J. (1992) "Economics, Organization and Management", Englewood Cliffs.

Mincer, J. (1974) "Schooling, Experience, and Earnings", New York: Columbia University Press

Montgomery, C. A. (1995) "Resource-Based and Evolutionary Theories of the Firm: Towards a Synthesis", Boston/Dordrecht/London: Kluwer Academic Publishers.

Pennings, L., K. Lee and A. van Witteloostuijn (1998) "Human capital, social capital, and firm dissolution", Academy of Management Journal, 425-440.

Praag, C.M. van (1996) "Determinants of Successful Entrepreneurship", dissertation, Amsterdam: Thesis Publishers.

Praag, C.M. van (1999) "Some classic views on entrepreneurship", De Economist 147(3), 311-335.

Praag, C.M. van and J.S Cramer (2001) "The roots of entrepreneurship and labor demand: individual ability and low risk aversion", Economica 269, 45-62.

Praag, C.M. van (2002), "Business Survival and Success of Young Small Business Owners: An Empirical Analysis", Small Business Economics, forthcoming.

Spence, Michael A. (1974) "Job Market Signaling: Informational Transfers in Hiring and Related Processes", Cambridge: Harvard University Press.

Wit, G. de and F. van Winden (1989) "An empirical analysis of self-employment in the Netherlands", Small Business Economics 1, 263-272. 


\section{APPENDIX: ESTIMATION OF THE MODELS}

Let $\Pi_{\mathrm{i}}$ be the profit for respondent $i$ in 1997, and $x_{i j}$ respondent $i$ 's value of determinant $j$ in 1994 . We specify the logarithm of profit as the dependent variable rather than profit it self because we argue that changes in the determinants influence relative profit rather than absolute profit (in e.g. euros). The model to be estimated then reads as follows:

$\ln \Pi_{i}=\alpha^{\Pi}+\sum_{j=1}^{J} \beta_{j}^{\Pi} x_{i j}+\varepsilon_{i}^{\Pi}, \quad$ where $\varepsilon_{i}^{\Pi} \sim N\left(0, \sigma_{\Pi}^{2}\right)$.

The model for employment is analogous to that for profit. Let $L_{i}$ be the cumulated employment (in full time equivalents) generated by respondent $i$ between 1994 and 1997, and $x_{i j}$ respondent $i$ 's value of determinant $j$ in 1994 . The regression equation then reads:

$\ln L_{i}=\alpha^{L}+\sum_{j=1}^{J} \beta_{j}^{L} x_{i j}+\varepsilon_{i}^{L}, \quad$ where $\varepsilon_{i}^{L} \sim N\left(0, \sigma_{L}^{2}\right)$.

Both the profit and the employment measures have zero as the lower bound. Negative profits are not observed, while negative employment is non-interpretable. Therefore, both equations are estimated using tobit regressions.

For duration, we apply a different model than for profit and employment, viz., a survival model. In this model the (logarithm of the) expected survival time is modelled as a function of the characteristics of the entrepreneurs. A description of this model is given below.

In the survival model, firm founders start their business at time $t=0$. Exits are described by a random process governed by a probability density function $f(t)$ and adjoining distribution function $F(T)$. Thus, the probability of a firm exiting between $t$ and $t+d t$ is denoted by $f(t) d t$ and the chance that a firm exits in the first $T$ months is denoted by $F(T)$.

Consequently, the survivor function $S(T)$, defined as the probability that a firm survives the first $T$ months, is equivalent to $1-F(T)$. Also, the hazard rate $\theta(t)$, specifying the conditional probability that a firm that has remained in business for a period from 0 to $t$, exits in the short interval $[t, t+d t]$, is equivalent to

$\theta(t)=\frac{f(t)}{S(t)}$.

The hazard function is modelled as a function of a set of exogenous person specific regressors, the vector $x$, and of time $t$ to permit duration dependence. Assuming the absence of regressors, the hazard is a non-monotonic function of $t$. The assumption was shown to hold by a first inspection of the duration data. A simple hazard specification that permits non-monotonic behavior is the log-logistic (Lancaster, 1992, p. 44):

$\theta(t, x)=\frac{k(x) \alpha t^{\alpha-1}}{1+k(x) t^{\alpha}}$

Let $k(x)=\exp (\beta, x)$. Then, it can be demonstrated that

$E\left[\ln t \mid x_{i}\right]=-\beta^{\prime} x_{i}{ }^{3}$.

These are the coefficients (i.e. $-\beta$ ) that are shown for duration in Table 2 . The likelihood function to be maximized is the following:

$L_{i}=S\left(t_{i}\right) \theta_{i}\left(t_{i}\right)^{d_{i}}$,

where $d_{i}=1$ if individual $i$ 's exit is observed at $t_{i}$ and $d_{i}=0$ if $i$ 's length of time in business is right censored. As

equation (1) can be rewritten as

$\theta(t)=\frac{-d \ln S(t)}{d(t)}$

it follows that

$S(t)=\exp \left(-\int_{0}^{t} \theta(u) d u\right)$.

The logarithm of the likelihood function can now be written in terms of the hazard function as

$\ln L_{i}=-\int_{0}^{t_{i}} \theta_{i}(u) d u+d_{i} \ln \theta_{i}\left(t_{i}\right)$.

${ }^{3}$ See Greene (2000), page 993. 